\title{
Language shift: local language proficiency of the younger generation in Lampung
}

\author{
Bambang Riadi \\ Department of Language and Arts Education \\ Correspondence : bambang.riadi@fkip.unila.ac.id
}

\begin{abstract}
Abstrak
Much research has been done on language shifting as a cultural product, but there is very little research on local language abilities and patterns, particularly in Lampung. Therefore, we aim to explain how local language skills and language patterns are among the younger generation. The descriptive method analyses the data obtained from the questionnaire given to the participants. The results showed that there had been a shift in local languages among the young generation of Lampung. The data explains that few young people are still fluent in local languages and use Indonesian to communicate in various domains. Thus, the younger generation gradually abandoned the local language as a cultural wealth of Indonesia. Study implications are also discussed, along with several recommendations for future studies.
\end{abstract}

Keywords: local language shift, language proficiency, language patterns

\section{Introduction}

Language shift refers to the speech community that prefers to use new languages in everyday conversations rather than old languages (Fasold, 1984) to impact the understanding of other languages. Language shift can result from language contact in a bilingual society (Darwis, 2011). Many studies on language shift globally, especially in minority languages (Cavallaro, 2005; Cho, 2015; Clyne et al., 1991; Fishman, 1977; Tannenbaum \& Berkovich, 2005; Yang, 2017). Attention to the maintenance of legacy languages needs to be done continuously, especially in the second generation (Kheirkhah \& Cekaite, 2015; Yang, 2017) because inherited languages are considered as personal, social, and national resources (Brecht \& Ingold, 2002; Zhang \& Slaughter-Defoe, 2009).

As a multicultural and multilingual country (Sunarti et al., 2019), research on language development is also widely carried out, especially in regional languages. Several studies state that there has been a shift in the local language spoken by Indonesian among the younger generation (Cohn \& Ravindranath, 2014; Musgrave, 2014; Nababan, 1985). This phenomenon is closely related to 
the status and function of Indonesian as the national language and the country's official language (Nababan, 1985). The study results show that minority languages are increasingly suppressed by Indonesian and other dominant languages (Arka, 2013). For example, the Tomini-Tolitoli language in North Sulawesi has experienced a rapid shift (Himmelmann, 2010 as cited in (Arka, 2013) ), there are even languages that have become extinct, namely Kayeli and Hukumina in Maluku (Gimes, 2010 as cited in (Arka, 2013). As is the case in other provinces in Indonesia, the shift in local languages among ethnic groups in Lampung may occur because the population of Lampung is also multiethnic. Apart from the Lampung ethnic group, the ethnic groups of the people of this province are very diverse from all over Indonesia, such as Javanese, Sundanese, Minang, Palembang, Bataknese, and Bugis (Sutarsyah \& Hasan, 2014).

Lampung residents get the following percentage: $61.88 \%(4,113,731$ people) Javanese, $11.92 \%$ (729,312 people) Lampung, $11.27 \%$ (749,566 people) Sundanese, 3.55\% (36,292 people) ) of the Semende tribe, and 11.35\% (754,989 people) of other tribes, such as Bengkulu, Batak, Minang, and Bugis (Danardana, 2008). With this multi-ethnic society, language shifts can occur in certain ethnic groups in Lampung. Research on the Lampung language shows that the young generation of the Lampung tribe tends to use their regional language in communicating in public spaces (Gunarwan, 1994; Wulandari, 2019), even the Lampung language can become extinct in their area (Septianasari, 2016). However, other findings suggest that the Lampung language is still well preserved in the villages of the Lampung tribe (Katubi, 2006). For non-Lampung tribes, it is found that the Balinese language in Lampung is still well preserved (Malini, 2014).

The findings of the development of local languages in Lampung still tend to focus on maintaining and shifting one language. Very few pay attention to the proficiency and patterns of language use in each communication domain. Research on understanding and moving regional languages in Lampung needs to be carried out to monitor the development of local languages as cultural products that need to be maintained. Therefore, this study aims to explain the level of local language proficiency and the patterns of language use in various domains by the younger generation in Lampung.

\section{Literature review}

\section{Language maintenance and language shift}

Language shift events occur in the language-speaking community when choosing to use a new language to replace the previous language (Fasold, 1984). Language shift occurs in the language left by the community of speakers (Sumarsono, 2007). This shift occurs from one language to another, not from one language variety to another in one language (Dorian, 1992). Thus, language 
preservation occurs when people choose to continue using language commonly used collectively (Holmes, 2013).

Maintenance of language and language shifting are like two sides of a coin (Fasold, 1991; Widianto, 2018; Zulaeha, 2017). Both happened at the same time. If a language survives, there will be no language shift. Conversely, if a language shifts, there will be no language maintenance. Language shift occurs not in a short time but takes a long time, at least two to three generations (Putri, 2018). In addition, the shifting and maintenance of a language are determined by many factors that are interrelated with one another. These factors can come from the ethnicity of the language used or outside the language user. Specific influences can cause the shift and maintenance and the extinction of a language.

One of the causes of language shift is diglossia. The term diglossia refers to linguistic situations in monolingual and multilingual societies, which have their respective roles and functions according to their designation (Ferguson, 1959). In a diglossic society, each language has its function according to its users to express their desires through social norms in the society concerned. In general, Indonesians speak two languages: the regional language and the Indonesian language, which is said to be a bilingual community. Local languages are generally used in the family domain or in communicating with interlocutors of the same ethnicity. In contrast, Indonesian is used to communicate with other tribes and formal domains, such as education and government.

\section{Language choice}

Multilingual societies have various codes, both language and dialect, for various domains. The language domain can be defined as constellation, location, conversation topic, and speaker relation (Fishman, 1978). These spheres can be in the form of the family domain, the environmental domain, the realm of work, religion, and the realm of government (Fishman, 1978). For example, when a wife talks to her husband about her child's problems, the conversation is relaxed. The relationship that exists between husband and wife. This condition is called the family domain. However, if a husband and wife discuss their child's problems with their teacher at school, the situation will become formal. The relationship that occurs between parents and teachers. This situation is called the educational domain.

Several factors influence language selection: 1) place and atmosphere of speech, 2) participants to speak, 3) purpose of speaking, 4) subject matter, 5) tone of speech, 6) norms of speech, and 7) type of speech (Hymes, 2005). In addition, another opinion states that four social factors influence a person in delivering a speech, namely participatory, social background and context, the topic of conversation, and the function (intent and purpose) of speech (Holmes, 2013). This study, to see the trend patterns in the use of regional languages 
based solely on the relationship between roles, speech events, and places where speech occurs. Thus, in communicating with interlocutors, language skills greatly influence speakers choosing the language used.

Furthermore, the choice of language can be related to someone's language proficiency. Someone's language proficiency can be grouped into several levels: Distinguished, Superior, Advanced, Intermediate, and Novice (Alexandria, 2012)). This study classifies regional language proficiency into three levels: advanced, intermediate, and elementary. Advanced, that is, someone has understood and can speak and understand the language used to communicate as desired. Intermediate understands basic vocabulary and can talk about simple vocabulary, but if using complex sentences, it is still confusing. Elementary is someone who knows the language, but if they are still superficial or unable to speak at all.

\section{Method}

This study used a descriptive method and used a sample of participants, namely university students from various ethnic groups from different regions of Lampung. The research location was conducted at the University of Lampung. The data used were obtained from a questionnaire designed to inquire about the proficiency of regional languages and the languages used in various domains. The number of participants was 638 university students with the following details.

Table 1 Data on participants by gender

\begin{tabular}{llll}
\hline No & Gender & $\mathbf{f}$ & $\mathbf{\%}$ \\
\hline $\mathbf{1}$ & Male & 131 & 20,4 \\
\hline $\mathbf{2}$ & Female & 507 & 79,6 \\
\hline & Total & 638 & 100 \\
\hline
\end{tabular}

Table 1 provides information on the gender of the participants, namely 131 male and 507 female participants.

Table 2 Data on participants by region of origin

\begin{tabular}{llll}
\hline No & City & $\mathbf{f}$ & $\mathbf{\%}$ \\
\hline $\mathbf{1}$ & Bandar Lampung & 162 & $\mathbf{2 5 , 3 9 1 8}$ \\
\hline $\mathbf{2}$ & Metro & 38 & 5,95611 \\
\hline $\mathbf{3}$ & South Lampung & 57 & 8,93417 \\
\hline $\mathbf{4}$ & West Lampung & 39 & 6,11285 \\
\hline $\mathbf{5}$ & North Lampung & 32 & 5,01567 \\
\hline $\mathbf{6}$ & East Lampung & 78 & 12,2257 \\
\hline $\mathbf{7}$ & Central Lampung & 72 & 11,2853 \\
\hline
\end{tabular}




\begin{tabular}{llll}
\hline $\mathbf{8}$ & Pesawaran & 60 & 9,40439 \\
\hline $\mathbf{9}$ & Tanggamus & 42 & 6,58307 \\
\hline $\mathbf{1 0}$ & Pringsewu & 44 & 6,89655 \\
\hline $\mathbf{1 1}$ & Pesisir Barat & 34 & 5,32915 \\
\hline $\mathbf{1 2}$ & Tulang Bawang & 35 & 5,48589 \\
\hline $\mathbf{1 3}$ & West Tulang Bawang & 36 & 5,64263 \\
\hline $\mathbf{1 4}$ & Waykanan & 37 & 5,79937 \\
\hline $\mathbf{1 5}$ & Mesuji & 34 & 5,32915 \\
\hline & Total & 638 & 100 \\
\hline
\end{tabular}

Table 2 provides information on the participant's area of origin. Participants came from various regions in Lampung Province, namely Bandar Lampung City (25.39\%), Metro (5.98\%), South Lampung (8.93\%), West Lampung (6.11\%), North Lampung (5.01\%), East Lampung (12.22\%), Central Lampung (11.28\%), Pesawaran (9.40\%), Tanggamus (6.58\%), Pringsewu (6.89\%), Pesisir Barat (5.32\%), Tulang Bawang (5.48\%), West Tulang Bawang (5.64\%), Way Kanan (5.79\%), and Mesuji (5.32\%). Most participants came from Bandar Lampung.

Table 3 Participant data based on ethnic groups

\begin{tabular}{llll}
\hline No & Ethnic & $\mathbf{f}$ & $\mathbf{\%}$ \\
\hline $\mathbf{1}$ & Lampung & 135 & 21,1599 \\
\hline $\mathbf{2}$ & Javanese & 312 & 48,9028 \\
\hline $\mathbf{3}$ & Sundanese & 43 & 6,73981 \\
\hline $\mathbf{4}$ & Semendo & 24 & 3,76176 \\
\hline $\mathbf{5}$ & Minangkabau & 20 & 3,1348 \\
\hline $\mathbf{6}$ & Balinese & 21 & 3,29154 \\
\hline $\mathbf{7}$ & Bataknese & $\mathbf{2 2}$ & 3,44828 \\
\hline $\mathbf{8}$ & Palembang & 49 & 7,68025 \\
\hline $\mathbf{9}$ & other & 12 & 1,88088 \\
\hline & Total & 638 & 100 \\
\hline
\end{tabular}

Table 3 provides information on the ethnicity of the participants. It seems clear that the participants come from ethnic groups: Lampung (21.15\%), Javanese (48.90\%), Sundanese (6.73\%), Semendo (3.76\%), Minangkabau (3.13\%), Balinese ( 2.39\%), Bataknese (93.44\%), Palembang (7, 68\%), and other ethnic groups (1.88\%).

\section{Findings}




\section{Local language proficiency level}

The level of local language proficiency is grouped into three, namely the advanced group, namely the participants have understood and can speak and understand very well so that communication occurs as desired; intermediate, that is, participants understand how basic vocabulary and participants can speak simple speech, but if using complex sentences it is still confusing for participants at this level; the elementary group, namely participants have knowledge of regional languages but if they practice it is still deficient. The results of the data analysis can be seen in the following table.

Table 4 Data on local language proficiency levels

\begin{tabular}{cccc}
\hline No & $\begin{array}{c}\text { Regional language proficiency } \\
\text { levels }\end{array}$ & $\mathbf{f}$ & $\mathbf{\%}$ \\
\hline $\mathbf{1}$ & Advanced & 265 & 41,471 \\
\hline $\mathbf{2}$ & Intermediate & 299 & 46,7919 \\
\hline $\mathbf{3}$ & Elementary & 74 & 11,5806 \\
\hline & Total & 638 & 99,8435 \\
\hline
\end{tabular}

Table 4 provides information on participants with minimum local language skills at the advanced level (41.47\%). Most of the participants have not properly used the local language, classified as intermediate $46.79 \%$, and elementary $11.58 \%$.

\section{Local language usage patterns}

This section provides information about the patterns of language use in various domains. We explain ways of language use based on role relationships, patterns of language use based on events, and patterns of language use based on places.

Table 5 Language use patterns based on role relationships

\begin{tabular}{|c|c|c|c|c|c|c|c|c|c|}
\hline \multirow[t]{3}{*}{ No } & \multirow{3}{*}{$\begin{array}{l}\text { Role } \\
\text { Relationships }\end{array}$} & \multicolumn{6}{|c|}{ Use of Language } & & \\
\hline & & \multicolumn{2}{|c|}{$\begin{array}{l}\text { Local } \\
\text { Language }\end{array}$} & \multicolumn{2}{|c|}{$\begin{array}{l}\text { Indonesian } \\
\text { Language }\end{array}$} & \multicolumn{2}{|c|}{$\begin{array}{l}\text { Local } \\
\text { Language } \\
\text { and } \\
\text { Indonesian } \\
\text { Language }\end{array}$} & & \\
\hline & & $\mathbf{f}$ & $\%$ & $\mathbf{f}$ & $\%$ & f & $\%$ & $\mathbf{f}$ & $\%$ \\
\hline 1 & $\begin{array}{l}\text { Parents (father } \\
\text { and mother) }\end{array}$ & 180 & 28,213 & 261 & 40,91 & 197 & 30,88 & 638 & 100 \\
\hline 2 & Siblings & 142 & 22,257 & 329 & 51,57 & 167 & 26,18 & 638 & 100 \\
\hline 3 & Grandparents & 235 & 36,834 & 204 & 31,97 & 199 & 31,19 & 638 & 100 \\
\hline 4 & Relatives & 120 & 18,809 & 273 & 42,79 & 245 & 38,4 & 638 & 100 \\
\hline
\end{tabular}


Table 5 provides information about the patterns of language use based on role relationships, namely with parents, siblings, grandparents, and relatives. $40.91 \%, 51 \%$, and $42 \%$ of participants chose to use Indonesian when communicating with their parents, siblings and relatives. In comparison, $36 \%$ chose to use local languages when communicating with their grandparents.

Table 6 Language usage patterns based on events

\begin{tabular}{|c|c|c|c|c|c|c|c|c|c|}
\hline \multirow[t]{3}{*}{ No } & \multirow[t]{3}{*}{ Events } & \multicolumn{6}{|c|}{ Use of Language } & & \\
\hline & & \multicolumn{2}{|c|}{$\begin{array}{l}\text { Local } \\
\text { Language }\end{array}$} & \multicolumn{2}{|c|}{$\begin{array}{l}\text { Indonesian } \\
\text { Language }\end{array}$} & \multicolumn{2}{|c|}{$\begin{array}{l}\text { Local } \\
\text { Language } \\
\text { and } \\
\text { Indonesian } \\
\text { Language }\end{array}$} & & \\
\hline & & $\mathbf{f}$ & $\%$ & $\mathbf{F}$ & $\%$ & f & $\%$ & f & $\%$ \\
\hline $\mathbf{1}$ & $\begin{array}{l}\text { Among friends with } \\
\text { the same ethnic group }\end{array}$ & 189 & 29,624 & 221 & 34,64 & 228 & 35,74 & 638 & 100 \\
\hline 2 & $\begin{array}{l}\text { To older people with } \\
\text { the same ethnic group }\end{array}$ & 169 & 26,489 & 280 & 43,89 & 189 & 29,62 & 638 & 100 \\
\hline 3 & $\begin{array}{l}\text { To younger people with } \\
\text { the same ethnic group }\end{array}$ & 149 & 23,354 & 324 & 50,78 & 165 & 25,86 & 638 & 100 \\
\hline
\end{tabular}

Table 6 provides data on patterns of language use based on speech events when speaking outside the family domain or by circumstances. Participants preferred regional languages (29.62\%) less than Indonesian (34.64\%) and mixed codes (local language and Indonesian language) (3.74\%) when speaking with their ethnic friends. The same thing happened when participants talked to older people and younger people of the same ethnicity; they used Indonesian, namely $43.89 \%$ and $50.78 \%$.

Table 7 Language usage patterns based on place

\begin{tabular}{|c|c|c|c|c|c|c|c|c|c|}
\hline \multirow[t]{3}{*}{ No } & \multirow[t]{3}{*}{ Place } & \multicolumn{6}{|c|}{ Use of Language } & & \\
\hline & & \multicolumn{2}{|c|}{$\begin{array}{l}\text { Local } \\
\text { Language }\end{array}$} & \multicolumn{2}{|c|}{$\begin{array}{l}\text { Indonesian } \\
\text { Language }\end{array}$} & \multicolumn{2}{|c|}{$\begin{array}{l}\text { Local } \\
\text { Language } \\
\text { and } \\
\text { Indonesian } \\
\text { Language }\end{array}$} & & \\
\hline & & $\mathbf{f}$ & $\%$ & $\mathbf{f}$ & $\%$ & $\mathbf{f}$ & $\%$ & $\mathbf{f}$ & $\%$ \\
\hline $\mathbf{1}$ & Campus & 0 & o & 523 & 81,97 & 115 & 18.03 & 638 & 100 \\
\hline 2 & Worship Place & 22 & 3.4483 & 471 & 73.82 & 145 & 22.73 & 638 & 100 \\
\hline 3 & Government agencies & 2 & 0.3135 & 623 & 97.65 & 13 & 2.038 & 638 & 100 \\
\hline 4 & Market & 41 & 6.4263 & 409 & 64.11 & 188 & 29.47 & 638 & 100 \\
\hline 5 & Neighbourhood & 145 & 22.727 & 322 & 50.47 & 171 & 26.8 & 638 & 100 \\
\hline
\end{tabular}

Table 7 provides information about language use based on where the speech occurs. Participants prefer to use Indonesian when speaking with speech 
partners such as on-campus (81.97\%), places of worship (73.82\%), government agencies (97.65\%), markets (64.11\%), and the environment they live (50.47\%).

\section{Discussion}

Based on the research results, only a tiny portion of the younger generation, from various ethnic groups, mastered the local language up to advanced, namely only 41.47\%. This phenomenon occurs because participants rarely use local languages in their interactions in each domain. As the basis for local language education, communication in the family realm has begun to shift to Indonesian. Parents should be able to maintain the local language by teaching their children. Intergenerational language maintenance depends on how parents plan and modify its use patterns according to family needs (De Houwer, 2007). This language shift event in the family realm can indicate the extinction of a language (Ernawati \& Usman, 2019). Therefore, the role of the family is significant in the development of a language as the results of the study explain that several families who have succeeded in raising bilingual children have built associations between each language and the domain of use in certain places, specific contexts, or certain people or their combinations (Fillmore, 1989).

In addition, when communicating with speech partners of the same ethnicity, most respondents prefer to use Indonesian or mixed codes between Indonesian and regional languages. Ideally, if the interlocutor is from the same tribe, they will communicate using the local language. Local language functions to share with people who have the same local language background.

Judging from the place, the participants prefer to use Indonesian when speaking with their speech partners. Campus environments, places of worship, government agencies, and markets are public places where participants can meet people from various ethnic groups. As explained that the population of Lampung is multiethnic, the choice of Indonesian should be used to facilitate interethnic communication. Furthermore, the Indonesian language is mostly used in the neighbouring domain or where the participants live. This can happen because the participants live in a multiethnic environment, and very few live in a monoethnic environment. However, if participants know that the interlocutor is from the same ethnic group, they must use the local language in either domain. But this was not done by many of them.

Based on this explanation, we found that there has been a shift in the local language in Lampung. They dominantly choose to use Indonesian in every domain. They make this pattern because their local language skills are not good. This means that regional languages, as one of Indonesia's cultural treasures, are starting to be abandoned by the younger generation.

\section{Conclusion}


There has been a shift in the local language in the younger generation of Lampung. This research shows that most (41.47\%) of the younger generation are not fluent in local languages. In addition, the patterns of local languages based on the relationship between roles, places or environments, and events, the younger generation tends to prefer Indonesian over local languages. In fact, because of their inability to speak the local language, the participants mixed codes for Indonesian and local languages. We think that this local language shift can impact the preservation of Indonesian culture because language and culture are an inseparable unity (Brown, 2000; Jiang, 2000).

This study has several implications. This is because it is found that there has been a shift in local languages, as seen from a small proportion of respondents who are fluent in local languages and the patterns of language use by respondents who prefer to use Indonesian. Based on these conditions, understanding local languages needs special attention from various parties, both the government and the language-speaking community. Of course, this cannot be separated from the role of family and society in encouraging the use of local languages in various places (Lee, 2002; Phinney et al., 2001). Furthermore, the government can include local language education in the curriculum in schools. The younger generation does not need to be ashamed of using local languages in all domains.

However, this study has limitations. Although this study has explained the shifting of regional languages in the younger generation in Lampung, this study only applies to the sample we took. In other words, we did not generalise our findings across Lampung and even Indonesia. Therefore it is necessary to research regional language skills with many participants. In addition, it is also essential to study the impact on the maintenance of other local cultures, such as local arts.

\section{Daftar pustaka}

Alexandria, V. (2012). American Council on the Teaching of Foreign Languages. American Council on the Teaching of Foreign Languages (ACTFL)/National Council for.

Arka, I. W. (2013). Language management and minority language maintenance in (eastern) Indonesia: strategic issues. Language Documentation \& Conservation, 7.

Brecht, R. D., \& Ingold, C. W. (2002). Tapping a national resource: Heritage languages in the United States. Eric Digest. Eric Clearinghouse on Languages and Linguistics. Retrieved October,

Brown, H. D. (2000). Principles of language learning and teaching (Vol. 4). Longman New York.

Cavallaro, F. (2005). Language maintenance revisited: An Australian perspective. Bilingual Research Journal, 29(3), 561-582. 
Cho, G. (2015). Perspectives vs. Reality of Heritage Language Development: Voices from Second-Generation Korean-American High School Students. Multicultural Education, 22(2), 30-38.

Clyne, M. G., Clyne, M., \& Michael, C. (1991). Community languages: the Australian experience. Cambridge University Press.

Cohn, A. C., \& Ravindranath, M. (2014). Local languages in Indonesia: Language maintenance or language shift. Linguistik Indonesia, 32(2), 131-148.

Danardana, A. S. (2008). Persebaran bahasa-bahasa di Provinsi Lampung. Kantor Bahasa Provinsi Lampung.

Darwis, M. (2011). Nasib bahasa daerah di era globalisasi: Peluang dan tantangan. Workshop Pelestarian Bahasa Daerah Bugis Makassar, Parepare.

Dorian, N. C. (1992). Investigating obsolescence: Studies in language contraction and death. Cambridge University Press.

Fasold, R. (1984). The sociolinguistics of society. Ch. 6. Language Attitudes. Basil Blackwell, Oxford.

Fasold, R. (1991). The sociolinguistics of society. Wiley-Blackwell.

Ferguson, C. A. (1959). Diglossia. word, 15(2), 325-340.

Fishman, J. A. (1977). Language and ethnicity. Language, ethnicity and intergroup relations, 15, 25 .

Fishman, J. A. (1978). The sociology of language: An interdisciplinary social science approach to language in society. Newburry House Publ.

Gunarwan, A. (1994). The encroachment of Indonesian upon the home domain of the Lampung language use: A study of the possibility of a minorlanguage shift. Seventh International Conference on Austronesian Linguistics. Leiden,

Holmes, J. (2013). An introduction to sociolinguistics. Routledge.

Hymes, D. (2005). Models of the interaction of language and social life: toward a descriptive theory. Intercultural discourse and communication: The essential readings, 4-16.

Jiang, W. (2000). The relationship between culture and language. ELT journal, $54(4), 328-334$.

Katubi, O. (2006). Lampungic languages: looking for new evidence of the possibility of language shift in Lampung and the question of its reversal. Tenth International Conference on Austronesian Linguistics. Puerto Princesa, the Philippines,

Kheirkhah, M., \& Cekaite, A. (2015). Language maintenance in a multilingual family: Informal heritage language lessons in parent-child interactions. Multilingua, 34(3), 319-346.

Lee, J. S. (2002). The Korean language in America: The role of cultural identity in heritage language learning. Language culture and curriculum, 15(2), 117-133.

Malini, N. N. S. (2014). Dynamics of Balinese language in the transmigration area of lampung province. e-Journal of Linguistics.

Musgrave, S. (2014). Language shift and language maintenance in Indonesia. In Language, Education and Nation-building (pp. 87-105). Springer.

Nababan, P. (1985). Bilingualism in Indonesia: Ethnic language maintenance and the spread of the national language. Asian Journal of Social Science, 13(1), 1-18. 
Bambang Riadi

Phinney, J. S., Romero, I., Nava, M., \& Huang, D. (2001). The role of language, parents, and peers in ethnic identity among adolescents in immigrant families. Journal of youth and Adolescence, 30(2), 135-153. 